\title{
THE USE OF FOCUS GROUP TO ELICIT RELEVANT DIRECTION ON INFORMATION SYSTEMS SKILLS
}

\author{
Rosarito Sánchez-Morcilio, University of Puerto Rico, Río Piedras Campus, rosarito.sanchez@upr.edu \\ Francisco Quiles-Torres, University of Puerto Rico, Río Piedras Campus, francisco.quiles@upr.edu
}

\begin{abstract}
This paper presents the results of a focus group conducted in 2012, among Information Systems (IS) alumni from the Caribbean region; to obtain relevant direction on IS skills, based on their experiences as IS professionals. The focus group, as well as the computer-assisted tool used, is explained. The most significant IS skill categories, in order of importance, were listed. The majority of those skills were consistent with the results of previous studies conducted in other geographical areas, which tend to indicate alumni of different cultural and geographical areas share the same challenges as IS professionals. The additional IS skills categories identified in this study were: negotiation with clients about a possible and cost-effective solution as well as awareness and use of innovative technology equipment. This study contributes to the IS body of knowledge by providing a unique description for each IS skill category, new additional IS skill categories, and the order of relevancy for the IS skill categories. The results of this study are only considered to be applicable to the sample used, so generalizations should be done with caution, as it is true for other research methods. The replication of this study can be done by using similar samples.
\end{abstract}

Keywords: Information Systems skills, Focus group for Information Systems research, Information Systems curriculum assessment, Information Systems alumni and Information Systems Curricula.

\section{INTRODUCTION}

Conducting Information Systems (IS) research relevant to the practice is crucial to ensure its results can be applied to the field (Rosemann \& Yaverbaum, 2007) [17]. The authors suggested that focus group is a useful technique to perform this task. The use of focus groups in IS research has gained popularity according to Burgess (2010), who explained that the interactions among the focus group participants can generate significant results [4].

Various authors had coincided that alumni are an ideal group of participants to conduct research studies. According to Grant, Hackney, and Edgar, alumni collaboration can enhance the IS curricula by providing significant information about the demands of today's workplace [9]. Similarly, Preciado-Ortiz, Zepeda-Ibarra, Castañeda-Palomera, and Ortega-Ojeda as well as Van-Auken, Chrysler, Gricenko-Wells, and Simkin stated alumni feedback is relevant since this group is considered a key stakeholder [14] and [21]. Since alumni already know the IS curriculum, for Van-Auken et al., they provide targeted recommendations. In fact, De-la-Torre-Pérez et al. indicated alumni add value to the curriculum assessment because there IS industry experience [6]. Additionally, Van-Auken, et al. explained alumni feedback is relevant since this group is considered a key stakeholder. Alumni provide targeted recommendations because this group already knows the IS curriculum [21].

Curriculum objectives need to be aligned with the business environment in such a way that it meets their purpose of existence. Constant changes in the IS career are causing challenges in tailoring IS curriculum to meet the local and regional needs (Topi, Valacich, Wright, Kaiser, Nunamaker, Sipior, and De Vreeda, [20]). According to Reichgelt and Yaverbaum, frequent communication with alumni help in keeping the IS curriculum updated to address the dynamic changes in the business environment [16].

Information Systems Faculty faces the challenge of designing a curriculum capable of preparing its graduates to become successful in their careers. The integration between alumni and the business community can be beneficial when facing this challenge (Plice and Reinig, [13]). Saulnier established both IS 2010 guidelines (Topi, et al., [20]) and the ABET Computing Accreditation Commission requirements (ABET, [1]) highlighted the importance of maintaining the IS curriculum relevancy in meeting the needs of the IS graduates to be successful in the their careers [18]. 
This article presents the results of a focus group conducted in 2012 of alumni of an IS program. Its purpose was to find out what are the most important IS skills based on their experiences as IS professionals and how the IS curricula could be enriched.

\section{Research objective}

The research objective of this study was to answer two questions:

1- What are the most important IS skills based on the alumni's experiences as IS professionals?

2- How IS curricula could be enriched by the alumni's experiences as IS professionals?

\section{Literature Review}

\section{The use of focus group}

Greenbaum stated focus group is a qualitative market research technique in which a group of eight to ten participants of common demographics, attitudes, or purchase patterns are led through a discussion, which usually last about two hours, of a particular topic by a trained moderator. More than eight participants are too difficult to moderate [10]. In fact, Fern recommends four to eight participants [8].

Among the benefits of the focus group are that participants can concentrate on the topic of discussion, with a healthy environment, which nourishes the discussion. The usual duration of the focus group is approximately two hours long (Greenbaum, [10]). By using automated data collection tools, such as such as electronic mail, chat, online discussion boards, and wikis the use of focus groups can be enhanced (Burgess, [4]).

The group moderator should be sensitive, creative, confident, and have a good communication skills to be able to manage the group. He or she should establish rapport but control of the group so that the conceptual areas, required for the study, are discussed, as well as generate an atmosphere where all participants' points of view are expressed (Fern, [8]). Greenbaum stated the moderator should be a good listener and has the ability to remain in the objective of each conceptual area to be covered at all cost [10]. As Krueger and Casey explained, the moderator is usually the head of the research [12].

Chenail, Cooper, and Desir suggested the moderator to present the conceptual areas of research in an organized manner in an appropriate environment for discussion [5]. The structure for the focus group, as Bickman and Rog advised, needs to be well organized. Questions can be used to guide the discussion so that all conceptual areas of the study are covered [3].

Krueger and Casey established the focus group should be homogeneous but, with some variations among participants [12]. Burgess explained there are two main ways to conduct focus group: online focus group and traditional "face to face". For online focus groups, the use of group support systems such as email, chat, and bulletin boards are tools required. For "face to face" focus groups, a note-based tool, managed by the moderator, can be used to collect data [4]. The quality of this approach is directly related to the ability of the moderator to capture relevant notes for the research (Krueger and Casey, [12]). Following the Chenail et al. approach, the researcher must be knowledgeable in the IS area and be receptive to innovative concepts about the topic when annotating and analyzing data [5].

For a focus group to have exploratory tasks, the moderation of more than one group is required, as Fern established. Generalizations of the study can be claimed if it is exploratory in nature [8]. Greenbaum advised audiotaping to recall key information that may be missed in written notes [10]. According to Krueger and Casey, audiotaping is not required if the annotator have great note-taking skills [12].

Bickman and Rog indicated that one of the limitations of focus groups is that its results cannot be generalized to larger populations [3]. To overcome this limitation, Fern stated, when selecting the sample, to stratified population and to select the sample randomly. Verification of results is key to increase the possibilities for the generalizations 


\section{Issues in Information Systems}

Volume 14, Issue 2, pp.269-278, 2013

of results to larger populations, providing rigor to the study since its results can be similar to the ones obtained by another experience researcher [8].

Bickman and Rog clarified that many books and research papers on focus group dedicate more effort in explaining the mechanics on how to conduct it and less endeavor to describe on the data analysis. There is no best or correct approach to the analysis of focus group data. The nature of the analysis should be determined by the research question and the purpose for which data is collected. Computer-assisted tools for content analysis are available for data analysis. Those tools work based on a key word in context (KWIC), which categorizes participants' impressions and feelings. The use of a computer-assisted tool makes easier for another researcher to verify the results and compare them to his or her study results [3].

Krueger and Casey explained data analysis for focus group should be based on pattern identification to discover new ideas about the topic of discussion. Using a computer-assisted tool can easily be used in pattern identification for data analysis [12].

\section{Previous studies to assess IS skills}

Recent studies had being conducted to assess alumni opinions regarding IS curricula. Van Auken et al. presented the set of skills that the alumni should have [21], while De-la-Torre-Pérez, Roa-Rivera, Saldivar-González, Muñozdel-Real, Roa-Rivera, and García-Cabrales showed alumni recommendations to the IS curriculum [6].

Van Auken et al. study, conducted on the West Coast of United States, had a sample of 46 alumni, who had three to five years of field experience, requesting them through a questionnaire to rank ten IS knowledge and skills areas [21]. The skills, in order of importance, were:

- Improving the ability in the development of workable solutions to information systems problems

- Understanding the concepts of the functional areas of a business such as marketing, and finances

- Effective writing communication skills, specifically showing an understanding of the functional areas of business in relation to each other

- Effective communication skills, specifically using business language

- Possessing the ability to identify an information systems problem

- To have quantitative skills or the ability to work with numerical data

- To have the ability to effectively work in teams

- To have technical preparation and the ability to use software such as spreadsheets, statistical packages, database packages

- To have the necessary oral communication skills.

On the other hand, De-la-Torre-Pérez et al. study, conducted in Mexico, reflected alumni recommendations for the IS curricula through a focus group. In their study, alumni gave recommendations based on their job experiences [6]. The recommendations were to improve the IS curriculum study plan in the following areas:

- Certifications

- Management administration

- Cisco certification

- Web ownership

- Marketing techniques

- Networks

- Communications

- Microsoft (software)

- Education. 


\section{Issues in Information Systems}

Volume 14, Issue 2, pp.269-278, 2013

\section{METHODOLOGY}

The main goal of the study, performed in 2012, was to perform an experiential focus group, in which alumni shared their career experiences to elicit important IS skills. The focus group, a vis-à-vis meeting, was also exploratory in nature since its participants expressed their unique thoughts. The main researcher was a college professor, who also served as the moderator for the group. Alumni, who participated on the focus group, did not know the professor before hand. They all graduated from the same IS curriculum. Their participation was based on their experiences at their current job positions as IS professionals from a Caribbean Metropolitan area.

Sixty alumni who graduated from 2005 to 2011 were invited to the focus group by electronic mail. A random sample of eight participants was used. One alumnus graduated in 2001, another in 2004, two in 2005, another in 2006, another one graduated in 2010, and two others in 2011.

The focus group used had homogeneity, as all participants were IS specialists. The variations among participants were based on their roles, which consisted of managerial (two) as well as non-managerial positions (one) in IS consulting firms, government agencies (one), universities (one), banking (one), and accounting/auditing (two). The sample obtained included representation from various IS areas and was considered adequate for this study.

\section{Data Collection}

To cover the conceptual areas of the study, which are the IS skills, open-ended questions were asked to participants. The answer to each question became input data for the study, as shown on Table 1.

Table 1: Conceptual areas of the study and the questions used

\begin{tabular}{|c|l|l|}
\hline & \multicolumn{1}{|c|}{ Conceptual Areas (Ramos [15]) } & \multicolumn{1}{|c|}{ QS skills } \\
\hline 1 & $\begin{array}{l}\text { Professional skills: To implement and manage in- } \\
\text { formation systems in an organization. }\end{array}$ & $\begin{array}{l}\text { What are the professional skills you demonstrate as an } \\
\text { IS professional? }\end{array}$ \\
\hline 2 & $\begin{array}{l}\text { Technology skills: To apply technological, analyti- } \\
\text { cal, and critical thinking skills in the solution of } \\
\text { problems related to information systems in organiza- } \\
\text { tions. }\end{array}$ & $\begin{array}{l}\text { What are the technology skills you are required to have } \\
\text { as an IS professional? }\end{array}$ \\
\hline 3 & $\begin{array}{l}\text { Information Systems context skills: To take into } \\
\text { consideration the context in which information sys- } \\
\text { tems operate, when being implemented and man- } \\
\text { aged. }\end{array}$ & $\begin{array}{l}\text { How do you manage to understand the IS environment } \\
\text { where the IS operates? }\end{array}$ \\
\hline 4 & $\begin{array}{l}\text { Life-long learning skills: To maintain his/her profes- } \\
\text { sional expertise by updating his/her knowledge in } \\
\text { technology and information systems. }\end{array}$ & How do you keep updated in the IS field? \\
\hline 5 & $\begin{array}{l}\text { Values and Soft skills: To perform his/her functions } \\
\text { showing respect and acknowledgement of ethics, } \\
\text { interpersonal relationships, communication, and } \\
\text { teamwork. }\end{array}$ & $\begin{array}{l}\text { What are the values and soft skills you demonstrate as } \\
\text { an is professional? }\end{array}$ \\
\hline
\end{tabular}

As a warm-up for dialogue, for every question, each participant was asked to write his or her answer in a piece of paper for its later discussion. Participants were able to fluently contribute to the discussion since they were already familiar with the questions. The researcher annotated all verbal comments expressed by each participant. Data collection was very easy to accumulate because it was gathered through their written answers and their verbal comments, which were annotated by the moderator. This discussion lasted two and a half hours.

\section{Limitation of the Study}

One limitation of this study is that generalizations of results apply only to the sample, since just one focus group was used. The moderation of more than one focus group is advisable for the study to have an exploratory task (Fern,[8]). 


\section{Issues in Information Systems}

Volume 14, Issue 2, pp.269-278, 2013

Yet, the results of this study provides valuable data on IS skills as reported by IS professionals from the Caribbean region, which can be compared to the results of similar studies conducted in other geographical areas.

\section{Data Analysis}

Data was analyzed by the classifying the focus group discussion, with the support of a computer-assisted tool, OpenCode 3.6 [11], to discover the key word context (KWIC) patterns. The KWIC is an option within the tool, which can be available at no cost by the Department of Health from University of Umeå.

The classification of alumni comments was divided into five different IS skill areas, which were professional, technological, information systems context, life-long learning, as well as values and soft skills. The KWIC, within each classification, represents a category supporting an IS skill. The KWIC helped determining the most repeated buzzwords, which then were ranked. This tool allowed to interpret the participants' expressions and feelings about the conceptual areas presented to them.

\section{Demographics}

\section{RESULTS}

Alumni, who participated, demonstrated to be working successfully as IS professionals. Vast majority of the alumni call themselves as Information Systems (IS) consultants. Twenty-five percent of the alumni indicated to be working for the banking industry. Thirteen percent indicated that they to be working for the state government. Twelve percent work for accounting services. Another twelve percent work in education.

Most alumni are currently working for a company that has more than a hundred employees. Thirty-eight percent of the alumni indicated that they are working in a company of eleven to fifty employees. The rest of the participants indicated to be working for a company of one to ten employees.

\section{Findings}

The researcher took a total of 54 annotations from the participants' opinions during the discussion in the focus group session. Figure 1 shows the distribution of annotations between the verbal comments and the written remarks. Recall, written remarks were capture for warm-up purposes before the verbal discussion began.

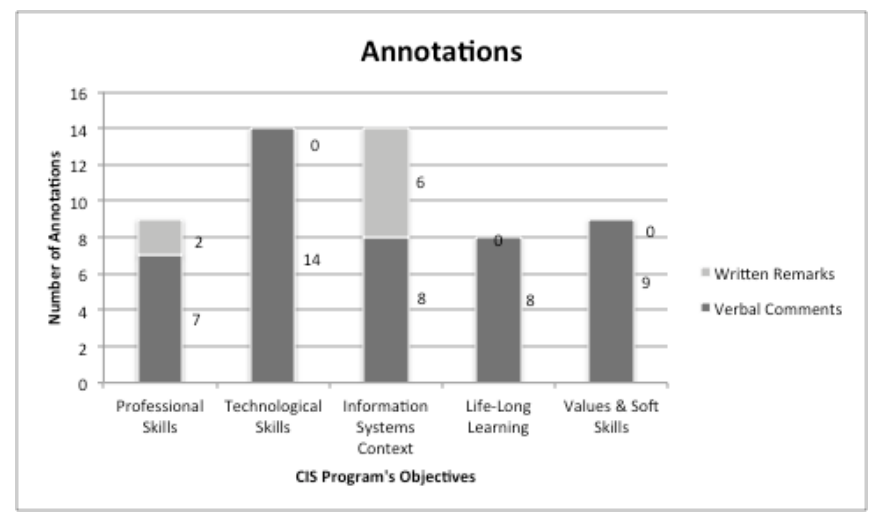

Figure 1: Annotations taken by the researcher

A total of 84 categories were found. A summary of this information is presented in Table 2.

Table 2: Categories per Classification

\begin{tabular}{|c|l|c|}
\hline Key & \multicolumn{1}{|c|}{ Classifications } & $\begin{array}{c}\text { Total number of } \\
\text { categories }\end{array}$ \\
\hline 1 & Professional skills & 31 \\
\hline
\end{tabular}


Issues in Information Systems

Volume 14, Issue 2, pp.269-278, 2013

\begin{tabular}{|r|l|c|}
\hline \multicolumn{1}{|c|}{ Key } & \multicolumn{1}{|c|}{ Classifications } & $\begin{array}{c}\text { Total number of } \\
\text { categories }\end{array}$ \\
\hline 2 & Technological skills & 29 \\
\hline 3 & IS context skills & 7 \\
\hline 4 & Life-long learning skills & 11 \\
\hline 5 & Values \& Soft skills & 6 \\
\hline & Total & $\mathbf{8 4}$ \\
\hline
\end{tabular}

From each category (KWIC), a number of occurrences were registered and ranked. The higher this number is, the closer its association to an IS skill. Only the highest numbers, within each category, were considered significant for this study. The most significant categories, in order of importance, were negotiation with clients about a possible and cost-effective solution, comprehension and use of updated applications, identification of a specific solution as problem-solvers, awareness and use of innovative technology equipment, understanding of customers' need within their IS environment, knowledge of business process, law, software, and hardware, as well as, communication using business language. Those relevant categories are presented in Table 3.

Table 3: Relevant categories for IS skills

\begin{tabular}{|l|l|l|c|}
\hline & \multicolumn{1}{|c|}{$\begin{array}{c}\text { Category (KWIC) } \\
\text { Relevant to an IS skill }\end{array}$} & \multicolumn{1}{|c|}{ Category description } & $\begin{array}{c}\text { Number of } \\
\text { Occurrences within each cate- } \\
\text { gory (KWIC) }\end{array}$ \\
\hline 1 & Negotiation & $\begin{array}{l}\text { Negotiation with clients } \\
\text { about a possible and cost- } \\
\text { effective solution. }\end{array}$ & 20 \\
\hline 2 & Applications & $\begin{array}{l}\text { Comprehension and use of } \\
\text { updated applications. }\end{array}$ & 16 \\
\hline 3 & Solution & $\begin{array}{l}\text { Identification of a specific } \\
\text { solution as problem- } \\
\text { solvers. }\end{array}$ & 12 \\
\hline 4 & Hardware & $\begin{array}{l}\text { Awareness and use of in- } \\
\text { novative technology } \\
\text { equipment. }\end{array}$ & 12 \\
\hline 5 & Customer relationship & $\begin{array}{l}\text { Understanding of custom- } \\
\text { ers' need within their IS } \\
\text { environment. }\end{array}$ & \\
\hline 6 & Knowledge & $\begin{array}{l}\text { Knowledge of business } \\
\text { process, law, software, and } \\
\text { hardware. }\end{array}$ & 6 \\
\hline 7 & Communication & $\begin{array}{l}\text { Communication using } \\
\text { business language. }\end{array}$ & 5 \\
\hline
\end{tabular}

\section{Comparison of the results with previous studies}

The results of this study present consistency with previous ones. Such common aspects are shown in Table 4.

Table 4: Comparison of the results with previous studies

\begin{tabular}{|c|c|c|c|}
\hline $\begin{array}{c}\text { Category description } \\
\text { results for this study } \\
\text { (Caribbean) }\end{array}$ & $\begin{array}{c}\text { Results for the Van Auken et } \\
\text { al. (2011) study } \\
\text { (US West Coast) }\end{array}$ & $\begin{array}{c}\text { Results for the De-la-Torre- } \\
\text { Pérez et al. (2012) } \\
\text { (Mexico) }\end{array}$ \\
\hline
\end{tabular}


Issues in Information Systems

Volume 14, Issue 2, pp.269-278, 2013

\begin{tabular}{|c|c|c|c|}
\hline & $\begin{array}{c}\text { Category description } \\
\text { results for this study } \\
\text { (Caribbean) }\end{array}$ & $\begin{array}{l}\text { Results for the Van Auken et } \\
\text { al. (2011) study } \\
\text { (US West Coast) }\end{array}$ & $\begin{array}{l}\text { Results for the De-la-Torre- } \\
\text { Pérez et al. (2012) } \\
\text { (Mexico) } \\
\end{array}$ \\
\hline 1 & $\begin{array}{l}\text { Negotiation with clients } \\
\text { about a possible and cost- } \\
\text { effective solution. }\end{array}$ & Not observed & Not observed \\
\hline 2 & $\begin{array}{l}\text { Comprehension and use of } \\
\text { updated applications. }\end{array}$ & $\begin{array}{l}\text { Use software such as spread- } \\
\text { sheets, statistical packages, da- } \\
\text { tabase packages. }\end{array}$ & $\begin{array}{l}\text { Recognize the importance of } \\
\text { certifications such as the Cisco } \\
\text { certification. Knowledge of the } \\
\text { Microsoft applications. }\end{array}$ \\
\hline 3 & $\begin{array}{l}\text { Identification of a specific } \\
\text { solution as problem-solver. }\end{array}$ & $\begin{array}{l}\text { Identify a business problem and } \\
\text { bring a workable solution. }\end{array}$ & Not observed \\
\hline 4 & $\begin{array}{l}\text { Awareness and use of in- } \\
\text { novative technology } \\
\text { equipment. }\end{array}$ & Not observed & Not observed \\
\hline 5 & $\begin{array}{l}\text { Understanding of custom- } \\
\text { ers' need within their IS } \\
\text { environment. }\end{array}$ & Not observed & $\begin{array}{l}\text { Work well in the web environ- } \\
\text { ment. } \\
\text { Show marketing skills to work } \\
\text { well with the customer. }\end{array}$ \\
\hline 6 & $\begin{array}{l}\text { Knowledge of business } \\
\text { process, law, software, and } \\
\text { hardware. }\end{array}$ & $\begin{array}{l}\text { Understand the functional areas } \\
\text { of business. }\end{array}$ & $\begin{array}{l}\text { Exhibit the interest to learn } \\
\text { about new topics to be educated. }\end{array}$ \\
\hline 7 & $\begin{array}{l}\text { Communication using } \\
\text { business language. }\end{array}$ & $\begin{array}{l}\text { Communicate using business } \\
\text { language. }\end{array}$ & $\begin{array}{l}\text { Demonstrate effective commu- } \\
\text { nication in general. The study } \\
\text { does not imply business lan- } \\
\text { guage as part of the communica- } \\
\text { tion skills. }\end{array}$ \\
\hline
\end{tabular}

There are two main areas in which the results of this study varied from the previous ones performed by Van Auken et al. (2011) and De-la-Torre-Pérez et al. (2012): negotiation with clients about a possible and cost-effective solution as well as awareness and use of innovative technology equipment. Those differences reveal critical IS skills necessary, according to alumni, to be successful in the market of their geographical area. Although the rest of the categories are similar among the studies presented, the way its description is expressed reflects unique reflections concepts regarding IS skills, except for the "communicate using business language".

\section{CONCLUSIONS}

This study used focus group to elicit relevant direction on IS skills. Participants of the study ilustrated what IS skills are important to be successful in the workplace as IS professionals. In spite of a small sample, their experiences in their respective jobs dictates emerging trends to what IS skills are appropriate. This study inspires future studies to be conducted to discover new patterns in the IS careers.

This study was both, experiential and exploratory, because it presented alumni experiences in the IS field as well as illustrated innovative and unique ideas from its participants as it gives directions toward what should be the emphasis to each IS skill discussed.

The results of this study can not be generalized to the whole population, as it is the case of other research methods. Nevertheless, important results were drawn from the results. Those are consistent with the results obtained by VauAuken et al., [21] and De-la-Torre-Pérez, [6]. This coherecy indicates rigor in the research conducted. In short, the majority of skills required by the IS professionals to be successful in the workplace are consistent across different cultural and geographical areas. Two important contributions of this study are its unique description for each IS skill category and new additional IS skill categories not found in the previous studies, which are negotiation with clients about a possible and cost-effective solution as well as awareness and use of innovative technology equipment. 
The third and main contribution of this study to the IS body of knowledge is the order of relevancy for the IS skill categories, being negotiation with clients about a possible and cost-effective solution, comprehension and use of updated applications, identification of a specific solution as problem-solvers, and use of innovative technology equipment, the most significant.

In addressing the research questions, the most important IS abilities were professional and technological skills, which received most emphasis from participants. The rest of the classifications, in order of importance, were lifelong learning, IS context, and lastly, values and soft skills.

IS curricula can be enriched by alumni's experiences as IS professionals by taking into consideration the relevant IS skills revealed by this study, as presented on Table 3, which describes relevant IS skill categories. Those categories are: negotiation with customers about a possible and cost-effective solution, identification of solutions as problemsolvers, comprenhension and use of updated applications, awareness and use of innovative technology equipment, understading of customers' need within their IS environment, knowledge of business process, law, software, and hardware, as well as communication using business language.

\section{Recommendations from this study to improve IS curricula}

To improve IS curricula, Table 2 shows relevant categories for IS skills. According to that table, many teaching tips can be elaborated for a holistic formation of IS professionals. Some teaching tips are:

1- Assign an extreme complex project, ideally from real life. Find companies in your area to help in this task. Ask the student to negotiate with you, as the professor/client, which activities are feasible in terms of budget, people, and time to have the project completed. During the negotiation, the student should show a clear understanding of the customer's needs within his/her IS environment. Then, allow the student to participate actively in the selection of the project and its complexities.

a. Such negotiation should be formal, as it would be with a real client. All agreements should be in writing, as it were a contract.

b. From the beginning of the negotiation to the delivery of the completed project, the student should demonstrate knowledge of the business process and the laws that may apply to the project.

2- To encourage the student to develop the ability to provide solutions for all class activities in different and innovative equipment environments, such as workstation and mobile.

3- Instead of assigning specific task to accomplish a class activity, let the student exchange ideas and agree upon what the specific solution for the activity should be. The agreement can be "the contract". This approach promotes negotiating skills along the curriculum, not just in the capstone project.

4- In advanced courses, motivate the student to demonstrate his/her knowledge of updated applications into the solution for an assigned class activity. Such updated applications can ideally be new and never taught in the curriculum. This activity boosts the student to learn by himself/herself the modern application, as it will be in real life. This assignment may represent more effort for the professor and a challenge for the student, but the result is a great learning experience for both parties.

5- To promote communication in the business language, invite a local entrepreneur to actually have a conversation with students, not just as a speaker. Let the invitee evaluate the student's ability to communicate effectively and give him or her feedback on how to do best next time. The communication is advised to be verbally. If verbal conversation is not possible, written communication works just as well.

6- The most important IS skill students should accomplish while in College is the enthusiasm of doing a great job to serve others.

\section{Future Direction}

Similar studies can be conducted to compare IS skills presented in this study. For example, this study's focus group results can be compared to the results from other focus groups, such as different IS students within the same University, IS students from other Universities in the region or from other geographical areas. According to Fern, the combination of, at least, three focus group results is more appropriate for the exploratory task, which allows generalizations to a whole population [8]. Those multiple data layers can produce significant knowledge regarding contemporary IS skills to enrich IS curricula. 


\section{REFERENCES}

1. ABET (2009). Criteria for accrediting computer programs: Effective for evaluations during the 2010-2011 accreditation cycle. Baltimore: ABET, Inc. Retrieved January 2010, from http://abet.org/uploadedFiles/Accreditation/Accreditation_Process/Accreditation_Documents/cac-criteria-20102011.pdf, 2-3.

2. Bhattacherjee, A. (2012). Social Science Research: Principles, Methods, and Practices (Second Ed.), Tampa, FL: Global Text Project.

3. Bickman, L., \& Rog, D. J. (2009). The sage handbook of applied social research methods. Thousand Oaks, Calif.: Sage Publications.

4. Burgess, S. (2010). The Use of Focus Groups in Information Systems Research. International Journal Of Interdisciplinary Social Sciences, 5(2), 57-68.

5. Chenail, R. J., Cooper, R., \& Desir, C. (2010). Strategically reviewing the research literature in qualitative research. Journal of Ethonographic \& Qualitative Research, 4(2010), 88-94.

6. De-la-Torre-Pérez, H., Roa-Rivera, R. O., Saldivar-González, S. J., Muñoz-del-Real, G., Roa-Rivera, G. I., \& García-Cabrales, P. G. (2012). Seguimiento a los egresados, función sustantiva de las demandas de un mercado laboral. Global Conference on Business and Finance Proceedings, 7(1), 836-841.

7. Downey, J. P., McMurtrey, M. E., \& Zeltmann, S. M. (2008). Mapping the MIS Curriculum Based on Critical Skills of New Graduates: An Empirical Examination of IT Professionals. Journal of Information Systems Education, 19(3), 351-363.

8. Fern, E. F. (2001). Advanced focus group research. Thousand Oaks, Calif.: Sage.

9. Grant, K., Hackney, R., \& Edgar, D. (2010). Informing UK Information Managemement pedagogic practice: The nature of contemporary higher education culture. International Journal of Information Management, 30(2010), 152-161.

10. Greenbaum, T. L. (2000). Moderating focus groups: a practical guide for group facilitation. Thousand Oaks, Calif.: Sage Publications.

11. ICT Services and System Development and Division of Epidemiology and Global Health (2009). OpenCode 3.4. University of Umeå, Sweden. Available from: http://www.phmed.umu.se/english/divisions/epidemiology/research/open-code/?languageId=1 [Accessed 2013/04/29].

12. Krueger, R. A., \& Casey, M. A. (2000). Focus groups: a practical guide for applied research. Thousand Oaks, Calif:: Sage Publications.

13. Plice, R. K., \& Reinig, B. A. (2009). Leveraging Alumni and Business Community Relations to Assess the Information Systems Curriculum. Journal of Education for Business, 84(3), 142-150.

14. Preciado-Ortiz, C. L., Zepeda-Ibarra, C., Castañeda-Palomera, A., \& Ortega-Ojeda, A. T. (2012). El grado de competencias del egresado de la licenciatura en turismo versus las capacidades genéricas exigidas por el mercado laboral. Global Conference on Business and Finance Proceedings, 7(1), 894-905.

15. Ramos A. (2008). Proposal for the computer information systems major redesign. Certification number 101 from the Academic Senate, University of Puerto Rico Río Piedras Campus, May 27, 2008. [Official University Document], 7-10.

16. Reichgelt, H., \& Yaverbaum, G. (2007). Accountability and accreditation: Putting information systems accreditation into perspective. Communications of the Association for Information Systems, 20(2007), 416-428.

17. Rosemann, M., \& Vessey, I. (2008). Toward improving the relevance of information systems research to practice: The role of applicability checks. MIS Quarterly, 32(1), 1-22.

18. Saulnier, B., \& White, B. (2011). IS 2010 and ABET accreditation: An analysis of ABET-accredited information systems programs. Journal of Information Systems Education, 22(4), 347-354. 


\section{Issues in Information Systems}

Volume 14, Issue 2, pp.269-278, 2013

19. Straus, A., \& Corbin, J. (1990). Basics of Qualitative Research: Grounded Theory Procedures and Techniques, Newbury Park: Sage.

20. Topi, H., Valacich, J. S., Wright, R. T., Kaiser, K., Nunamaker Jr, J. F., Sipior, J. C., \& De Vreeda, G.-J. (2010). IS 2010: Curriculum Guidelines for Undergraduate Degree Programs in Information Systems. Communications of AIS 2010(26), 359-428.

21. Van-Auken, S., Chrysler, E., Gricenko-Wells, L., \& Simkin, M. (2011). Relating gap analysis results to information systems programs attitudes: The identification of gap priorities and implications. Journal of Education for Business, 86(2011), 346-351. 